\title{
REQUEST STRATEGIES USED BY THE MAIN CHARACTER IN THE MOVIE “THE BLIND SIDE"
}

\author{
Astrinita Anantama Marchella1, Erwin Rahayu Saputra ${ }^{2}$ \\ State Islamic University Sunan Ampel Surabaya ${ }^{1}$, Universitas Siliwangi Tasikmalaya ${ }^{2}$ \\ astrinita.am@gmail.com ${ }^{1}$, rs_erwin@yahoo.com ${ }^{2}$
}

\begin{abstract}
This study focuses on the request strategies used by the female main character (Leigh Anne Tuohy) in the movie 'The Blind Side'. In conducting her analysis, the writer is very much indebted to Trosborg, 1995, especially, through his theory of request strategies. The writer used qualitative approach by applying interpretive framework in describing the data. Leigh Anne Tuohy's utterances which contain request strategies are the data source of this study. The results show that there are ten types of request strategies used by the female character in the movie. In addition to finding the types of request strategies, the writer also describes the situation and condition of the main character when she is giving the requests to some body else.
\end{abstract}

Keywords: request; request strategies; The Blind Side Movie.

\section{INTRODUCTION}

Language is an important device for human being in the world. They cannot live properly without language, because no one can live alone without contact with others. Knowing a language also means knowing how to use that language since speakers know not only how to form sentences but also how to use them appropriately (Wardaugh, 2006:3). Language also has two functions; transactional and interactional. Transactional is language serves in the expressions of content, and interactional is expressing social relations and personal attitudes (Brown and Yule, 1983). In daily life, all people use language for sharing ideas, showing expressions and feelings, and interacting with each other. Furthermore, with language one has an ability to convey, catch, and understand the messages in the conversation.

To get a response from others, people ask something or utter words containing thought, feeling, desires or needs to each other. When people produce utterances that contain words and grammatical structure, they usually do some actions through their utterances which are later called "speech act" (Finegan, 1992:307). Austin specifies speech acts into giving order, making promises, complaining, requesting, and refusing among others (Austin, 1962:98-99). For example, when a speaker invites someone to go to the party, she persuades the person using a polite request.

A request is an act used by people in the direct or indirect conversation. Direct request is an act of request when a speaker makes a request using performative verbs. Performative verbs are verbs where saying or writing it performs the action itself. Meanwhile, indirect 
request is an act of request when a speaker makes a request the form of which is not related to the function. It contains implicit meaning if she/he wants the do something.

Yule (1996) has divided speech act into five types of general functions; declarations, representatives, expressives, comissives, and directives. Directives is kind of speech act to get someone to do something, and express what the speaker wants (Yule 1996:54). Directive is to direct the hearer towards doing something; which has a world to word direction of fit, e.g. requests, ask question, suggestion, apologies, and so on (Mey in Searle, 1979:34-8).

Request as one of directive speech acts is called pre-event act. They express the speaker's expectation of the hearer with regards to prospective action; verbal or nonverbal (BlumKulka, House and Kasper (1989:11). Requests may be included as face-threatening act as hearers can interpret them as intrusive impingements on freedom of action; the speakers need to be competent in order to have a successful result in communication. The speakers may hesitate to make the request for fearing of exposing a need or risking the hearer's loss of face (Blum-Kulka, House and Kasper, 1989:11-12).

With regard to this, the researcher is interested in analyzing the request strategies in The Blind Side movie which is adapted from an extraordinary true story. This movie is based on a book The Blind Side: Evolution of a Game by Michael Lewis published in 2006. This movie is an American semi biographical sports drama film which is first published in 2009. The genre is drama movie. It was written and directed by John Lee Hancock. The Blind Side was a box office success movie which is grossing over $\$ 300$ million. This movie has received an Academy Award nomination for Best Picture.

The researcher is interested in analyzing conversation spoken by the female main character in The Blind Side movie which contains request strategies. The main character from the movie is Sandra Bullock as Leigh Anne Tuohy and Quinton Aaron as Sean Junior 'SJ'. This movie is telling about a poor, oversized and under-educated teenager recruited by a major college football program where he is groomed into an athletically and academically successful NFL prospect.

There are some reasons why the researcher is interested in analyzing request strategies used by the female main character in The Blind Side movie. Firstly, request is easily and commonly found in daily communication. Secondly, the main characters are the persons who play mostly in the movie and they often utter and have conversation with each other. 


\section{RESEARCH METHOD}

In this research, the researcher used qualitative approach. The researcher used interpretive framework where the instrument of this research is the writer herself. Through qualitative study, the reality that a view is different for different people under different conditions is highly respected. The data source were from the female main character (Ms. Tuohy) in The Blind Side movie, the duration of which is 128 minutes. The data were utterances spoken by the female main character in the movie which contain request strategies. All the data were interpreted and described by the researcher; this research is concerned with subjective opinions of the researcher. In conducting the analysis, the researcher was very much indebted to Trosborg's (1995) theory on request strategies.

\section{FINDINGS AND DISCUSSION}

This part presents findings of the research and discusses them. The findings presents data related to request strategies used by female characters. The findings show that Ms. Tuohy/Leigh Anne, the female character, makes sixty six requests by applying different strategies as follows: mild hints, strong hints, hearer's ability, hearer's willingness, suggestory formulae, statements of speaker's wishes and desires, statements of obligation and necessity, performatives, and imperatives.

\subsection{Mild Hints}

In this strategy, the speaker can leave out the desired action altogether (Trosborg, 1995). The speaker does not explicitly mention the desired action to the hearer. Hence, the hearer must figure out for him/ herself about the speaker's wishes. The example of Mild Hints strategy that Ms. Tuohy uses when she gives request to the woman can be seen in the following example.

\section{Data 1}

Leigh Anne : Just tell Gerald to hold on the chiffonier and I'll get by after while. You don't I got to call you back. Bye. Excuse me. I'm not cutting, I'm just asking. Let me tell you something, alright? We've been sitting around here for over an hour and when I look around and all I see is people shooting the bull and drinking coffee. Who runs this place? Well, I'd have it in shape in two days, I can tell you that.

Woman : I'd bet you would. How can I help you?

Leigh Anne :Oh, he was first. 
The dialogue takes place in the office. There are two people, Ms. Tuohy and a receptionist, in the dialogue. The topic in the dialogue is waiting for a call by the officer. Ms. Tuohy/ Leigh Anne goes to an office to get information to be a legal guardian. There, she wants to talk to a receptionist (a woman) about procedures that should be gone through to adopt a child (Michael). She has been waiting for about an hour, but no one calls her or gives her attention. Then, she warns the receptionist, because she has been ignored by the officer, just like the other people who have been waiting there.

Ms. Tuohy/Leigh Anne's utterances, “Let me tell you something, alright? We've been sitting around here for over an hour and when I look around and all I see is people shooting the bull and drinking coffee. Who runs this place? Well, I'd have it in shape in two days, I can tell you that" are considered as Mild Hints strategy because the expression makes no reference to the request proper but it is interpreted as a request in that context. The expression seems to be a statement without having its intended meaning as a request. However, this expression is considered as request expression in context because Ms. Tuohy/Leigh Anne's desire is wanting to talk to the woman about adopting a child. Therefore, she warns the woman with her condition in the office that she only sees staff who are just drinking coffee and shooting the bull. In conclusion, Ms. Tuohy/Leigh Anne did not explicitly ask the woman to call her name; thus, it is considered as Mild Hints strategy.

\subsection{Strong Hints}

In this strategy, the speaker's wish can be partially mentioned (Trosborg, 1995:192). However, the speaker only omits explicit mention of the hearer as the agent (Trosborg, 1995:193). The example of Strong Hints strategy that Ms. Tuohy uses when she gives request to Sean can be seen in the data below.

\section{Data 2}

\begin{tabular}{|c|c|}
\hline Leigh Anne & : Was this a bad idea? \\
\hline Sean & : What? \\
\hline Leigh Anne & $\begin{array}{l}\text { : Don't lie there and pretend like } \\
\text { you're not thinking the same thing as me. }\end{array}$ \\
\hline Sean & $\begin{array}{l}\text { : Fine, tell me what you're thinking } \\
\text { so I know what's supposed to be on my mind. }\end{array}$ \\
\hline Leigh Anne & : How well do you know Big Mike? \\
\hline Sean & $\begin{array}{l}\text { In case you haven't noticed he doesn't have much to say. What's the } \\
\text { big deal? It's just for one night, } \\
\text { right? It is just one night, right? }\end{array}$ \\
\hline Leigh Anne & $\begin{array}{l}\text { You don't think he'll steal anything, do you? I guess we'll know in } \\
\text { the morning. }\end{array}$ \\
\hline
\end{tabular}


The dialogue above happens in the bedroom. The conversation occurs between two people, Ms. Tuohy and Sean. The topic in the dialogue above is Michael. Ms. Tuohy/Leigh Anne is talking about Michael with Sean (her husband) in their room. She thinks that she wants to adopt Michael as their child. However, when she asks Sean, there is no response from him. Then, she states her dislike by using this statement, "Don't lie there and pretend like you're not thinking the same thing as me."

Ms. Tuohy's utterance is considered as a Strong Hints because the desired action of Ms. Tuohy (as the speaker) is partially mentioned. Here, Ms. Tuohy's desired action towards Sean is asking him about her idea. Hence, Ms. Tuohy desired action towards Sean is asking him to be honest about her idea and agree with that.

\subsection{Hearer's Ability}

This strategy is the condition of ability that refers to the hearer's capacity to perform the desired act. It can be said that it is asking about the hearer's ability to do something for the speaker. The example of Hearer's Ability strategy that Ms. Tuohy uses when she gives a request to Collins is as follows.

\section{Data 3}

Leigh Anne: Collins, can you pass me the green beans, please? Don't pick it with your fingers just take a spoon. Okay. SJ! Elbows! Sorry. So, Big Mike. You like to shop? Because tomorrow I think I'll have to show you how it's done.

The dialogue when preparing for breakfast above occurs in the Tuohy family's dining room. The utterance above is spoken by Ms. Tuohy or Leigh Anne to her daughter Collins, but there is no utterance spoken by Collins; she mainly does her mom's request. In the dining room, Ms. Tuohy/Leigh Anne prepares a breakfast for her family in the morning. She has cooked a big breakfast, because it is a thanksgiving celebration.

At that time, her husband and her child are eating their foods in front of TV. Ms. Tuohy sees Michael who eats his breakfast alone in the dining room. Since Ms. Tuohy wants to show her empathy to Michael, then she invites her other family members to eat the foods in the dining room. Her husband and her child are disappointed, because they cannot watch baseball on the TV while eating. Even though they are disappointed, they grant Ms. Tuohy's request. When all Tuohy's family start their breakfast in the dining room, Ms. Tuohy asks Collins to help her pass the green beans. 
Ms. Tuohy says Collins, can you pass me the green beans, please? to her daughter. The words 'Can you....?'. is included in the hearer-based pre-condition where the hearer must infer that the question concerns with his or her ability to carry out the specified act. This counts as an attempt on the part of the speaker to make the hearer to do the activity. In this context, Ms. Tuohy asks Collins's ability - and willingness - to bring her the green beans next to collins. Therefore, the utterance of Ms. Tuohy is included in Hearer's Ability strategy.

\subsection{Hearer's Willingness}

This strategy is a request of willingness that is asking whether the hearer is willing to do something or has any objection to do something. The speaker addresses the hearer as the agent of the action and usually used term 'Will you...' or 'Would you (like)' and 'Can/ May I...' (Trosborg, 1995:199). The example of Hearer's Willingness strategy that Ms. Tuohy used when she gives request to a man can be seen below.

\section{Data 4}

Man 1 : At least a dozen, probably. If not more. With her drug arrest record my guess would be she can't even remember.

Leigh Anne : May I see that? So we'd need her permission, right?

Man 1 : No. Michael is a ward of the state. Just apply and get a Judge to sign off on it.

The dialogue above happens in an office which processes a legal guardian. The conversation is between two people; Ms. Tuohy and an officer, who talk about Michael's file. Ms. Tuohy is in an office to make a legal adoption of Michael. Before she asks to an officer for processing a legal adoption of Michael, she wants to know the file of Michael. She wants to know what happened to Michael in the past, because she does not know anything about Michael. Therefore, Ms. Tuohy asks the permission to the officer.

Ms. Tuohy's utterances in the dialogue, "May I see that? So we'd need her permission, right?" is considered as asking the Hearer's Willingness using modal 'May...' in her request to the officer. According to Trosborg (1995:199), there is another way of asking about the hearer's willingness to do something, which is by making a request of permission. Usually the expression, 'Will you...' or 'Would you (like)...' is used. Here, Ms. Tuohy asks permission to the officer to give Michael's file to her. After Ms. Tuohy requests it, the officer gives Michael's file to her. Here, the requestee (the hearer) does something for the requester (the speaker). It can be said that Hearer's Willingness strategy used by Ms. Tuohy is successful. 


\subsection{Suggestory Formulae}

Suggestory formulae is a request which contains a suggestion to do something (BlumKulka, House \& Kasper, 1989:18). This strategy is able to make the speaker request more tentative and play down his or her interest as a beneficiary of the action. The key point in this strategy is the speaker and hearer do the action and gets the benefit of it. The example of suggestory formulae strategy that Ms. Tuohy uses when she gives a request to someone can be seen as follows.

\section{Data 5}

Leigh Anne : Collins, can you pass me the green beans, please? Don't pick it with your fingers just take a spoon. Okay. SJ! Elbows! Sorry. So, Big Mike. You like to shop? Because tomorrow I think I'll have to show you how it's done.

The utterance above happens when people have breakfast in the Tuohy family's dining room during thanksgiving celebration. The topic in the dialogue above is breakfast. Ms. Tuohy/ Leigh Anne prepares for a breakfast in the morning for thanksgiving celebration. She invites her family to eat together in the dining room. It is because her husband and her child are eating in front of TV while Michael is alone eating his breakfast on the table in the dining room. Before they eat their foods, they pray to God to bless them and give them a new friend, Michael. After that, they start to eat their food and SJ wants to pick the food by his hand. However, SJ's act makes his mom state her request.

Ms. Tuohy says, "Don't pick it with your fingers just take a spoon. Okay" to SJ. It is considered as suggestory formulae. The expression contains her suggestion to SJ to do something. When SJ picks the food using his fingers, Ms. Tuohy suggests SJ to do it using a spoon. The benefit of this action is for both of them, Ms. Tuohy and SJ. The benefit for Ms. Tuohy is teaching her child about politeness when eating or teaching about table manner to SJ, while the benefit for SJ is becoming familiar with politeness during eating the food on the table.

\subsection{Statements of Speaker's Wishes and Desires}

This strategy focuses on the speaker. In other words, the speaker makes a statement of request based on his or her wishes or desires (Trosborg, 1995:201). This strategy is more polite, because using term 'I would like you to...'. The example of statements of speaker's wishes and desires strategy can be seen when Ms. Tuohy gives a request to someone in the next data. 


\section{Data 6}

Woman : Ma'am, now you can tell me what you want or I'll make sure you wait all day. Now how can I help you?

Leigh Anne : I'd like to become a legal guardian.

Woman : Lord helps that child.

The dialogue happens in the morning in an office. There are two people in the dialogue, Ms. Tuohy and a woman or an officer. The topic in the dialogue above is child adoption. Ms. Tuohy goes to the office to legally adopt a child. However, she has been waiting there for about an hour and she watches the entire officer drink coffee and shoot the bull, but none calls her. After being complained, the officer accepts Ms. Tuohy's complains and asks what Ms. Tuohy wants.

Ms. Tuohy expresses her desire to the officer by saying, "I'd like to become a legal guardian. It is considered as statements of speaker's wishes and desires. Ms.Tuohy expresses that she wants the hearer to do something for her. The statements of speaker's wishes and desires based on his or her wishes and desires, and it sounds more polite. Here, Ms. Tuohy wants to become a legal guardian for Michael. She wants to know the procedure of how to become a legal guardian. The officer responds Ms. Tuohy's desire by searching the file of Michael. The officer also gives the step by step actions to do by Ms. Tuohy. Hence, it is a statements of speaker's wishes and desires strategy.

\subsection{Statements of Speaker's Needs and Demands}

This strategy is less polite, because the speaker directly gives a request to the hearer. It makes the hearer perform an act as the speaker's needs or demands (Trosborg, 1995:202). This strategy usually uses expressions like, 'want (I want...)' or 'need (I need...)' in making the request. The example of statements of speaker's needs and demands strategy that Ms. Tuohy uses appears in the following data.

\section{Data 7}

Man : That's terrible.

Leigh Anne : Tell me about it. He'll have nightmares about for a weeks._So when he comes to visit I want you to feed him Italian he likes Fettucine Alfredo and I want you to take him to a movie not Chainsaw Massacre because he'll just cover his eyes and get him to bed by ten. You got it?

Man : Yes'm. Alright. What about Tennessee?

The conversation happens in the Tuohy's family house. There are two people in the dialogue Ms. Tuohy and a man from NFL (baseball team). The topic in the dialogue above is 
taking care of Michael. In the morning, there is a man who comes to Tuohy's family house to propose Michael for his baseball team because his baseball ability of Michael is amazing. It makes several universities and baseball team invite Michael to join them. The invitation makes Tuohy's family happy. Then, Ms. Tuohy talks to the man who will bring Michael to the NFL (baseball team). She talks about the Michael's habit and preferences because she does not want her child to be in bad situations. She wants the best things for her child, Michael.

When negociating with the man about the benefits Michael can get, Ms. Tuohy says, "I want you to feed him Italian he likes Fettucine Alfredo and I want you to take him to a movie not Chainsaw Massacre because he'll just cover his eyes and get him to bed by ten. It is considered as Statements of Speaker's Needs and Demands strategy because the requester directly gives a request to the hearer to perform an act based on the speaker's needs and/ or demands. Here, Ms. Tuohy directly gives a request to the man to take care of her child, Michael. She also wants the man to let Michael watch movies. She wants the man to give the best service for her boy. Indeed, the speaker (Ms. Tuohy) uses the word 'Want...' to make her request ('I want you to...') which is in the form of statements of speaker's needs and demands.

\subsection{Statements of Obligation and Necessity}

This strategy states that the hearer is under the obligation to do a desired action. In addition, the hearer must be obliged to to do what the speaker wants or requests. This strategy usually uses terms like 'should' and 'ought to', 'have to', or 'must'. The example of statements of obligation and necessity strategy that Ms. Tuohy uses when she gives a request to someone can be seen below.

\section{Data 8}

Leigh Anne: You stopped it. You stopped it. This team is your family, Michael. You have to protect them from those guys. Okay Listen. Okay. Tony here is your quarterback, alright? You protect his blind side. When you look at him, you think of me. How you had my back. How you have his. Okay? Alright. Tony, go back. Alright. Oomaloompah here is your tailback. When you look at him, you think of SJ, how you never let anyone or anything to hurt him. You understand me? Alright. Go back. You got it?

Michael: What about Collins and Mr. Tuohy?

Leigh Anne: Fine. They can be on the team too. Are you gonna protect the family, Michael?

Michael: $\quad$ Yes, ma'am. 
The dialogue above occurs when Ms. Tuohy and Michael play baseball in the yard. Ms. Tuohy and SJ come to the filed to watch Michael's team play baseball. Ms. Tuohy watches the details of their play and SJ takes the video of the play. Then, Ms. Tuohy feels the play of baseball players is bad and the couch is less detail in teaching them. The couch, Bert, can only show his anger and grumble to his players. Because of this, Ms. Tuohy walks toward the baseball player where Michael, her child, is part of the team. Ms. Tuohy tries to teach the players authoritatively.

Ms. Tuohy says, "You have to protect them from those guys. Okay?" to Michael. It is considered as statements of obligation and necessity because the word 'have to..' expresses obligation to the hearers. Ms. Tuohy says to Michael that the team is like a family and must be protected from anything that can hurt his family. Her request gives an obligation to Micahel to protect his team from another team, because Michael is the protector of their team. After Ms. Tuohy coaches the baseball players, Micahel understands it and does what has been coached to him. Hence, the request is expressed in the form of a statements of obligation and necessity.

\subsection{Performatives}

This strategy is very direct and usually authoritative when the speaker gives a request to the hearer. The speaker can convey a request simply by using a performative verb. It is such as 'ask, request, order, demand, command', and etcetera (Trosborg, 1995:203). The example of Performatives that Ms. Tuohy uses when she gives a request to someone can be seen in the next data.

\section{Data 9}

Woman 1 : Leigh Anne, is this some sort of white guilt thing? What will your daddy say?

Leigh Anne: Umm... before or after he turns over in his grave? Daddy's been gone five years Elaine, make matters worse you were at the funeral. Remember? You were Chanel and that awful black hat. Look, here's the deal. I don't need y'all to approve my choices, alright? But I do ask you to respect them. You've no idea what this boy's been through. And If this is going to be some running diatribe I can find an overpriced salad a lot closer to home.

Woman 1 : Leigh Anne, I'm so sorry. We didn't intend to---

Woman : No. We didn't really.

The dialogue above happens in the restaurant. There are about five people involved in the dialogue, they are, Ms. Tuohy and her friends who are talking about Michael adoption. However, there are only three people talking. They are talking about their daily activities to 
each other. At that time, one of her friends talks about Michael who leaves with Tuohy's family. A woman says that Michael is like Jessica Lange and King Kong (a character in King Kong movie). Another woman makes a joke about how if Tuohy's family adopts Michael, and they think that it is impossible to do. Ms. Tuohy/ Leigh Anne just smile at them while eating her lunch. Then she tries to talk to her friends about her idea to adopt Michael as her child. All of the women shock and cannot believe in Leigh Anne's mind. The women complain and suggest that it is not a good choice. Ms. Tuohy feels annoyed about it and she says to her friend authoritatively, "I don't need y'all to approve my choices, alright? But I do ask you to respect them,"

It is considered as performative strategy because Ms. Tuohy/ Leigh Anne directly requests her friends by saying 'ask' to request her friends to respect Michael eventhouh they do not approve her choice. After listening to the request expression of Ms. Tuohy/ Leigh Anne, they feel sorry and respond to Ms. Tuohy, "Leigh Anne, I'm so sorry. We didn't intend to---“ In the perfomatives strategy, the speaker can convey a request simply by using a performative verb in their sentences, such as 'ask, request, demand, command.' In conclusion, Ms. Tuohy's utterances can be called performatives strategy.

\title{
3.10 Imperatives
}

This strategy is the grammatical form directly showing the utterances as an order (Trosborg, 1995:204). It is very authoritative and the speaker's request must be obeyed by the hearer. This strategy also has power to the hearer, for example orders from parents to their children, from teachers to pupils, from officers to soldiers, from employers to employees, and so on. The example of imperatives that Ms. Tuohy uses when she gives a request to someone is as follows.

\section{Data 10}

\author{
Leigh Anne : Who's that SJ? \\ SJ : Big Mike. \\ Leigh Anne : Get your feet off my dash. Thank you. Put on your seatbelt!
}

In the dialogue above that happens in a car, Ms. Tuohy/ Leigh Anne and SJ talk about going home. Before SJ is picked by his mom, he meets Michael in the play ground at school. They are talking for few minutes. Then from her car, Ms. Tuohy (SJ's mama) pushes the horn. SJ sees his mom and he runs fast to meet her. Ms. Tuohy says to SJ in the car, "Get your feet off my dash. Thank you Put on your seatbelt! It is considered as imperatives because Ms. 
Tuohy is very authoritative in asking SJ to move his feet from her desk. In the same situation, Ms. Tuohy very authoritative commands SJ to put the seatbelt for his safety. Even though in the dialogue there is no utterance spoken by SJ, but in the movie it is apparent that SJ does what his mama orders directly. In addition, the imperatives are the canonical grammatical form to get somebody to do something very authoritatively. In conclusion, the request expressions of Ms. Tuohy/ Leigh Anne above are included as imperatives.

\section{CONCLUSION AND SUGGESTION}

There are ten types of request strategies used by female (Ms. Tuohy) character in the movie. The writer found out that when giving request to someone, Leigh Anne Tuohy, a busy woman and a mother uses all request strategies suggested by (Trosborg, 1995). All request strategies were mild hints, strong hints, hearer's ability, hearer's willingness, suggestory formulae, statements of speaker's wishes and desires, statements speaker's needs and demands, statements of obligation and necessity, performatives, and imperatives.

Based on the findings the writer found out that the female character applies all request strategies when she was giving request to someone. It somewhat deviates from Holmes's (1982, 1986, 1990) statements that women tend to favor more polite and less direct form of request than men. More polite forms usually tend to be less direct. The data showing that the female character applies all strategies suggest that she does not only apply the less direct strategies, but also apply the direct ones.

This research is only a small scale research, which only uses a movie as its source of data and pays attention only to types of request strategies used by a female character. The writer recommends other researchers to conduct further studies about requests, for example, by involving social variables, such as, social status, age and so on. Further studies might also take data from other sources other than movies. Data collected from real life will give better portrayal of real application of request strategies by people in real societies.

\section{REFERENCES}

Austin. (1962). How to Do Things with Words. London: Oxford University Press.

Blum-Kulka, S. , House. J. , and Kaper, G (eds). (1989). Cross Cultural Pragmatics: Requests and Apologies (Advances in Discourse Processes, vol 31). Norwood NJ: Ablex Publisher. Brown, G. \& Yule, G. (1983). Discourse Analysis. Cambridge: Cambridge University Press. Finegan. (1992). Language: Its Structure and Use. Marickville: Harcourt Brace Jovanovich Group Pty Ltd 
Holmes, J. (1982). Expressing Doubts and Certainty in English. RELC Journal, 13(2):9-28.

Holmes, J. (1986). Functions of You Know in Women's and Men's Speech. Language in Society, 15:1-22.

Holmes, J. (1990). Hedges and Boosters in Women's and Men's Speech. Language and Communication, 10(3): 85-205.

Searle, J. R. (1979). Expression and Meaning in the Studies of Speech Act. Cambridge: Cambridge University Press.

Trosborg, A. (1995). Interlanguage Pragmatics: Requests, Complaints, and Apologies. Berlin: Mounton de Gruyter.

Wardhaugh, R. (2006). An Introduction to Sociolinguistics $5^{\text {th }}$ ed. UK: Blackwell Publishing. Yule, G. (1996). Discourse Analysis. New York: Oxford University Press. 